\title{
The Inhomogeneous Distribution of Tritium and Radiocarbon in the Abyssal Southern Ocean
}

\author{
Chen-Tung A. Chen \\ Institute of Marine Geology, \\ National Sun Yen-Sen University, Kaohsiung, Taiwan, R.O.C. \\ AND \\ MICHAEL R. RODMAN \\ 880 Hoxtel St. Gilroy, CA 95020, U.S.A. \\ (Received 12 March 1990; revised 22 May 1990)
}

\begin{abstract}
The tritium and radiocarbon measurements taken at the Southern Ocean GEOSECS stations were analyzed. Excess $\mathrm{CO}_{2}$ for the Atlantic GEOSECS stations $76,77,82,85,87,89,91$ and for all the stations of the SOMOV-81 cruise were correlated with the radiotracer data. Radiocarbon and excess $\mathrm{CO}_{2}$ support the tritium data showing that these tracers are not homogeneously distributed in the deep-water column. The preformed radiocarbon value of the Antarctic Surface water component in the Antarctic Bottom Water was estimated to be $-139.3 \times 10^{-3}$.
\end{abstract}

\section{INTRODUCTION}

The deep and bottom waters around Antarctica have been found to be quite homogeneous in the radiocarbon and excess $\mathrm{CO}_{2}$ concentrations and to a somewhat lesser extent in the tritium content. The presence of a bottom layer with clearly marked higher tritium values than in the deep water zone (e.g., typical bottom values of $>0.1 T U$ relative to deep water of about $0 T U$; $1 T U=10^{18} \mathrm{~T} / \mathrm{H}$ ) is well documented (Michel, 1978; Weiss et al., 1979 and Jenkins et al. 1983). This situation is interpreted to mean that bottom waters contain significant percentages of relatively young waters (i.e. waters of recent surface origin).

Radiocarbon value, on the other hand, has sometimes been reported to be very uniform regionally in the deep and bottom waters of the Antarctica, below the salinity and potential temperature maxima and the oxygen minimum. Values reported are $-163 \times 10^{-3}$ (Broecker, 1979; Fiadeiro, 1982), $-158 \times 10^{-3}$ (Stuiver, et al., 1983) and $-160 \times 10^{-3}$ (Stuiver, 1976; Broecker, 1981; Bolin, 1983). Excess $\mathrm{CO}_{2}$ has also been shown to be regionally uniform (Chen, 1982). 
These results may suggest that the bottom waters do not contain waters of recent surface origin.

Contrary to these reports, however, our study confirms the results of Weiss et al. (1979), Chen and Rodman (1984), Michel and Linick (1985), Chen and Drake (1986), and Poisson and Chen (1987) and shows that radiocarbon and excess $\mathrm{CO}_{2}$ are also non-homogeneous in deep to bottom waters, similar to the trend observed for tritium.

Radiocarbon values can be used for dating purposes only when both the initial (preformed) and measured values are known. Further, most deep and bottom waters in all major oceans contain some Antarctic Bottom Water (AABW). It is thus important to accurately describe the radiocarbon distribution in the AABW in order to obtain the preformed radiocarbon values.

\section{DATA}

The radiotracer and hydrographic data used in this study are from the Antarctic GEOSECS stations in the three oceans (Ostlund et al., 1976, 1979, 1980; Stuiver and Ostlund, 1980; Bainbridge, 1981; Broecker et al., 1982; Weiss et al., 1983) and the stations of the Weddell Polynya Expedition (WEPOLEX) (Huber et al., 1983) aboard the SOMOV. The Antarctic GEOSECS stations used were those containing a shallow temperature minimum and deep potential temperatures of less than $0^{\circ} \mathrm{C}$. Neither radiocarbon nor tritium were sampled on SOMOV; however, one GEOSECS station, GS 89 (22 Jan., 1973) at $60^{\circ} 1^{\prime}$ $S$ and $0^{\circ} 1^{\prime} E$ is very near one SOMOV station, SOMOV 33 (11 Nov., 1981) located at $59^{\circ} 59^{\prime} \mathrm{S}$ and $0^{\circ} 19^{\prime} \mathrm{E}$. The next two nearest GEOSECS stations to the SOMOV study area are GS 82 and GS 91 . The excess $\mathrm{CO}_{2}$ results are from Chen (1982, 1984, 1987), Chen and Poisson (1984) and Poisson and Chen (1987).

\section{DISCUSSION}

In Fig. 1 the vertical structures of tritium, radiocarbon and excess $\mathrm{CO}_{2}$ are displayed for the three GEOSECS stations nearest the SOMOV cruise track. The gross details are similar among the three variables in each station. For example, GS 89 shows a rapid decrease of tritium, radiocarbon and excess $\mathrm{CO}_{2}$ from the highest values at the surface to the minimum values near $250 \mathrm{~m}$ and then maintaining these generally low values to the bottom. GS 82 shows an increase only in tritium and $\Delta C-14$ for the bottom sample, but the deepest sample depth for excess $\mathrm{CO}_{2}$ is well above the bottom. The impression one gets is that below approximately $300 \mathrm{~m}$ these tracers are quite uniformly distributed in the water column. 


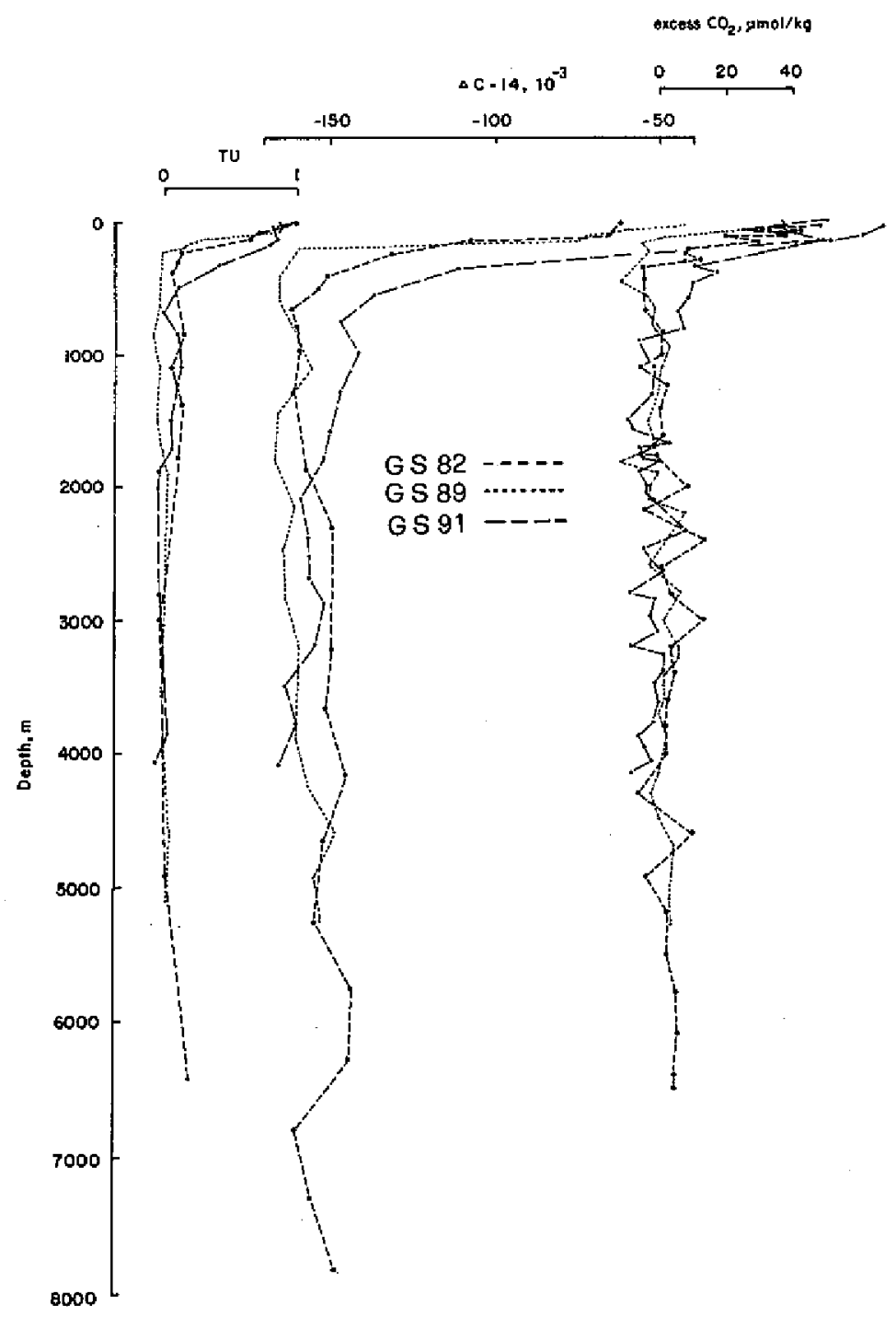

Fig. 1. Vertical distributions of tritium, $\left(1 T U=10^{18} T / H\right), \Delta C-14$ and excess $\mathrm{CO}_{2}$ near the SOMOV study area based on data from three GEOSECS stations, GS 82 , GS 89 , and GS 91 .

In Fig. 2, the same stations as Fig. 1 are plotted but with potential density $(\sigma \theta)$ rather than depth as the ordinate, and the SOMOV 33 excess $\mathrm{CO}_{2}$ results are also included. When potential density rather than depth is used, the structures of tritium and excess $\mathrm{CO}_{2}$ profiles are similar. Tritium and excess $\mathrm{CO}_{2}$ decrease to a minimum value at a $\sigma \theta$ of about 27.86 and then both parameters as well as $\triangle C-14$ show a gradual increase to the bottom.

Station 89 has anomalously higher tritium and radiocarbon at densities less than roughly $27.80 \sigma \theta$. This effect is not seen on the depth plot but is noticeable in other figures discussed later. We have no explanation for this phenomenon. 

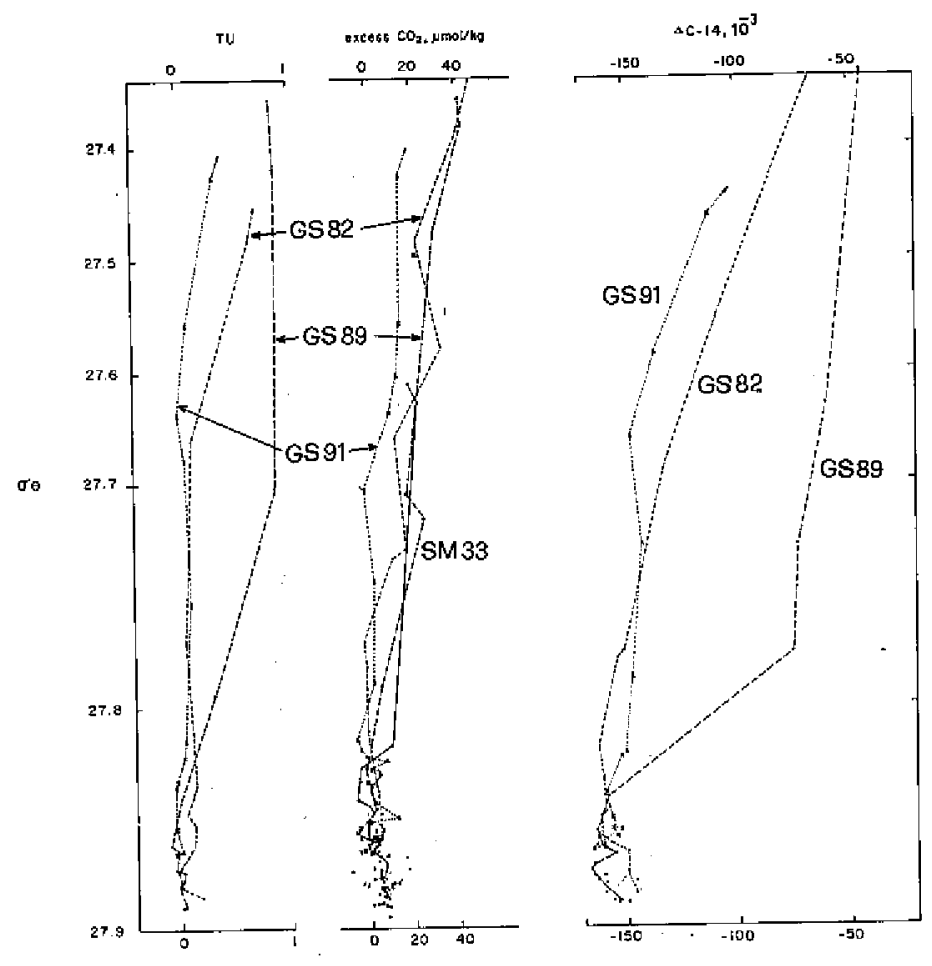

Fig. 2. Potential density vs tritium, $\left(1 T U=10^{18} T / H\right), \Delta C-14$, and excess $\mathrm{CO}_{2}$ from GEOSECS stations GS 82, GS 89, and GS 91. Excess $\mathrm{CO}_{2}$ for SOMOV 33 is also shown.

Excess $\mathrm{CO}_{2}$ at SOMOV 33 (Fig. 2) appears at relatively less dense layers than at GEOSECS stations. This difference, however, was found to be an artifact caused by the use of different equations of state for the GEOSECS data and for the SOMOV data. GEOSECS density values are systematically higher by $0.03 \sigma \theta$ units and $0.02 \sigma_{4}$ units than values obtained by using the international equation of state at one atmosphere and higher pressures (Millero et al., 1980; Millero and Poisson, 1981). Density data from SOMOV agreed to within $0.0002 \sigma$ units of the international equation. Figs. 3, 4,5 and 6 have the GEOSECS data scaled by subtracting $0.03 \sigma \theta\left(0.02 \sigma_{4}\right)$.

The poorer precision of radiocarbon and excess $\mathrm{CO}_{2}$ relative to tritium may obscure some information on the abyssal environment. We investigated this possibility by combining all the Antarctic GEOSECS and SOMOV stations in Figs. $3,4,5$ and 6 where tritium, radiocarbon and excess $\mathrm{CO}_{2}$ are plotted against potential density as the ordinate. Note that GEOSECS density in these figures has been scaled. The bottom values are clearly higher than the deep water values for all three parameters. Surface values are the highest and decrease to a broad minimum centered at about $\sigma \theta=27.85$, which is the density near, or just below the $S_{\max }$ layer (Carmack and Foster, 1975). The bottom 


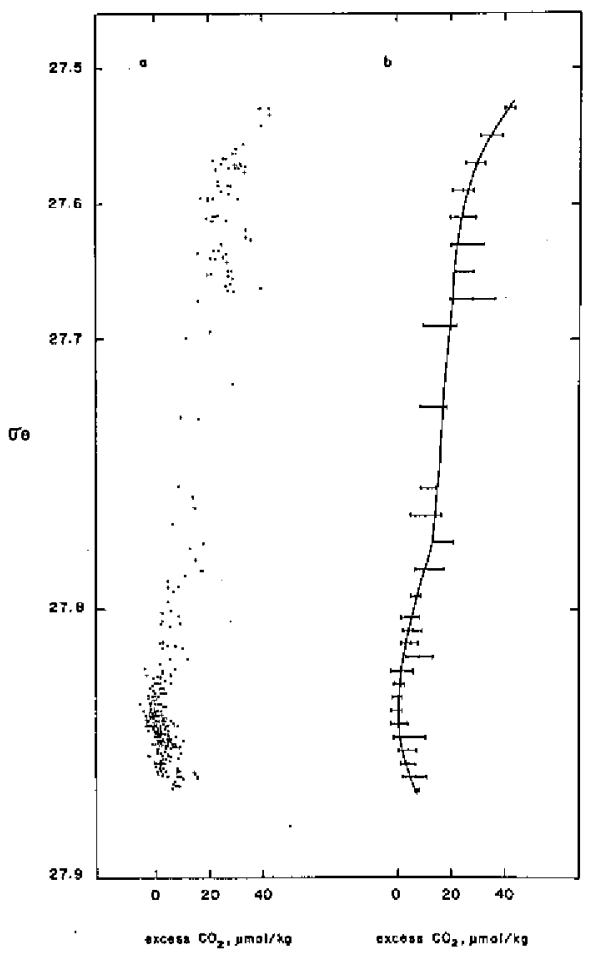

Fig. 3. (a) Composite GEOSECS potential density vs tritium for Atlantic (GS $76,77,78,82,89,91$ ), Pacific (GS 287) and Indian (GS 430, 431, 432, 433) Antarctic stations. (b) Curve fit by eye resulting from averaging data of $F i g .3 a$ in density bands. Points with no error bars indicate single-datum points.

layer increases by about 0.16 for tritium and $8 \times 10^{-3}$ for radiocarbon relative to their minima (Figs. 3,4). An increase near bottom for excess $\mathrm{CO}_{2}$ may exist in the GEOSECS data (Fig. 5). The increase is more clearly shown in the more precise SOMOV data (Fig. 6; Chen, 1984).

Shown also on Figs. 3, 4, 5, 6 are averages (and standard deviations) calculated for density bands with curves fit by eye through the averages. Averaging within density bands is justifiable because of the isopycnal spreading of water masses below the pycnocline (Reid et al., 1977). The choice of density bands was based on the number of data points contained therein and thus is somewhat arbitrary. The averaging intervals are as follows: for tritium and radiocarbon, 0.02 density units at $\sigma \theta \leq 27.7$ and 0.01 density units at $\sigma \theta>27.7$; for excess $\mathrm{CO}_{2}, 0.02$ density units at $\sigma \theta \leq 27.7,0.01$ density units at $27.7<\sigma \theta \leq 27.8$ and 0.005 density units at $\sigma \theta>27.8$. The curves for tritium, radiocarbon and excess $\mathrm{CO}_{2}$ are remarkably similar and show increases for waters denser than $\sigma \theta=27.85$. The precision and methodology for excess $\mathrm{CO}_{2}$ are apparently improved for the SOMOV data because of the tighter scatter of data points. The SOMOV excess $\mathrm{CO}_{2}$ data also indicate a break in slope near $\sigma \theta=27.78$ which 


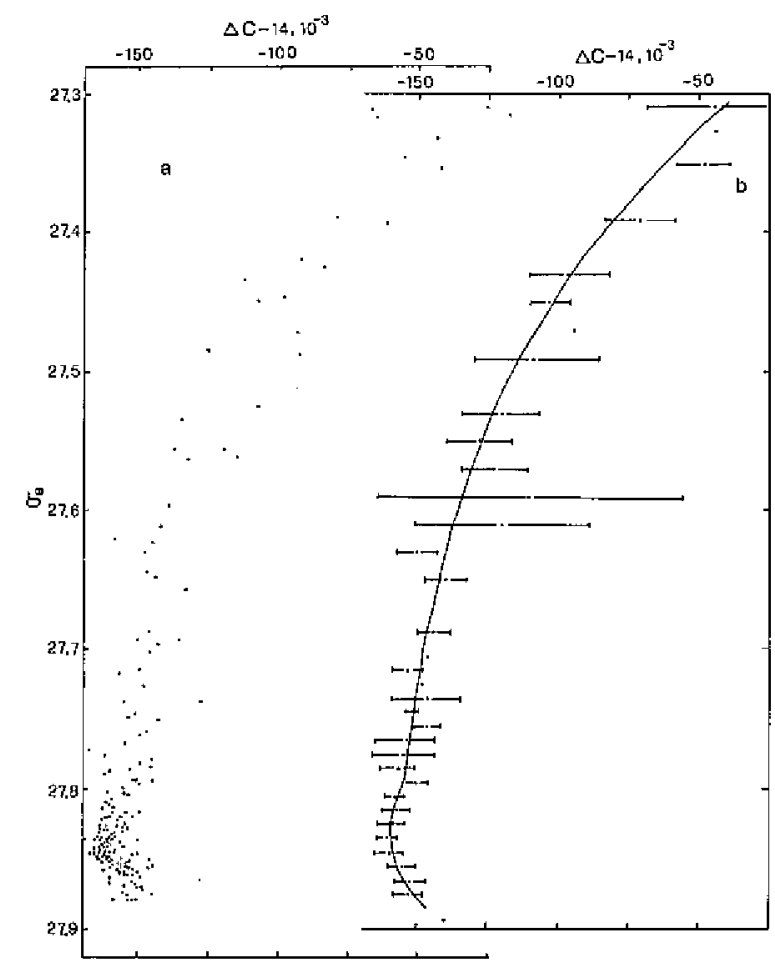

Fig. 4. (a) Same as Fig. 3a but for radiocarbon. (b) Same as Fig. 3b but for radiocarbon.

may be present in the GEOSECS tritium and radiocarbon data. It is interesting to note that this density surface lies near the base of the pycnocline for the SOMOV data and is also the isopycnal displaying some interleaving (Gordon and Huber, 1984; their Figs. 7 and 8). Wisegarver et al. (1989) also reported that chlorofluoromethanes in the southeast Pacific Ocean south of $55 S$ show a minimum at $\sigma \theta=27.8$ with concentrations increasing toward the bottom.

Excess $\mathrm{CO}_{2}$ data from SOMOV are again plotted in Fig. 7 but with $\sigma_{4}$ as the ordinate. Only data below the $S_{m a x}$ are plotted because $\sigma_{4}$ undergoes a minimum near the $\theta_{\max }$, as warmer water is less compressible than colder water (Lynn and Reid, 1968; Reid and Lynn, 1971). Using $\sigma_{4}$ effectively expands the deep water density scale compared to $\sigma \theta$ and confirms the results found from previous figures. An increased slope occurs near $\sigma_{4}=46.156$, and some indication of an offset to increased values exists at $\sigma_{4}=46.056$. These isopycnal surfaces have been investigated by Chen (1984). Briefly, breaks in scatter plots, in particular $\theta / p H$, at these two strata may indicate that surface to nearsurface components are exerting an influence at these depths, perhaps through isopycnal interleaving (Carmack and Kilworth, 1978; Jacobs and Georgi, 1977) or deep vertical convection (Gordon, 1978; Martinson et al., 1981). Three linear 

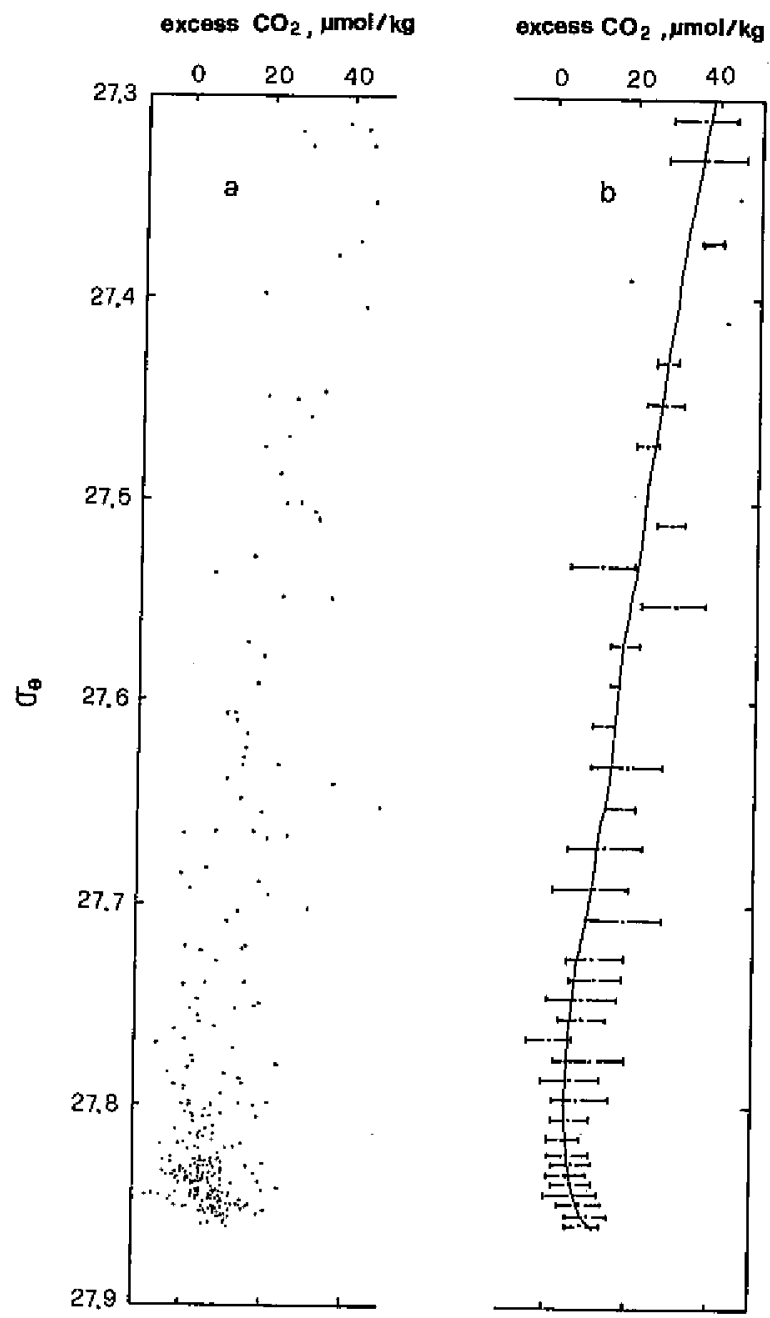

Fig. 5. (a) Composite potential density vs excess $\mathrm{CO}_{2}$ for Atlantic GEOSECS stations. (b) Curve fit by eye resulting from averaging data of $F i g$. 5 a in density bands. Points with no error bars indicate single-datum points.

regression lines were fit to these data, a) between $\sigma_{4}=46.000$ and 46.056 the slope is $7.3 \mathrm{~kg}^{2} / \mu \mathrm{mol} / \mathrm{m}^{3}$, b) between $\sigma_{4}=46.056$ and 46.156 the slope is $1.1 \mathrm{~kg}^{2} / \mu \mathrm{mol} / \mathrm{m}^{3}$, c) and below $\sigma_{4}=46.156$ the slope is $49.8 \mathrm{~kg} / \mu \mathrm{mol} / \mathrm{m}^{3}$. Three regimes, therefore, are indicated, with the deepest regime having the most significant slope. As was done for $\sigma \theta$, averages (and standard deviations) were calculated (the interval was 0.01 density units). Instead of a curve two linear relations were fitted. The deeper short segment (for data below $\sigma_{4}=$ 46.14) shows a well-defined increase, and the overall trend shows a general increase with depth.

Composite scatter of potential temperature, tritium and radiocarbon vs. 


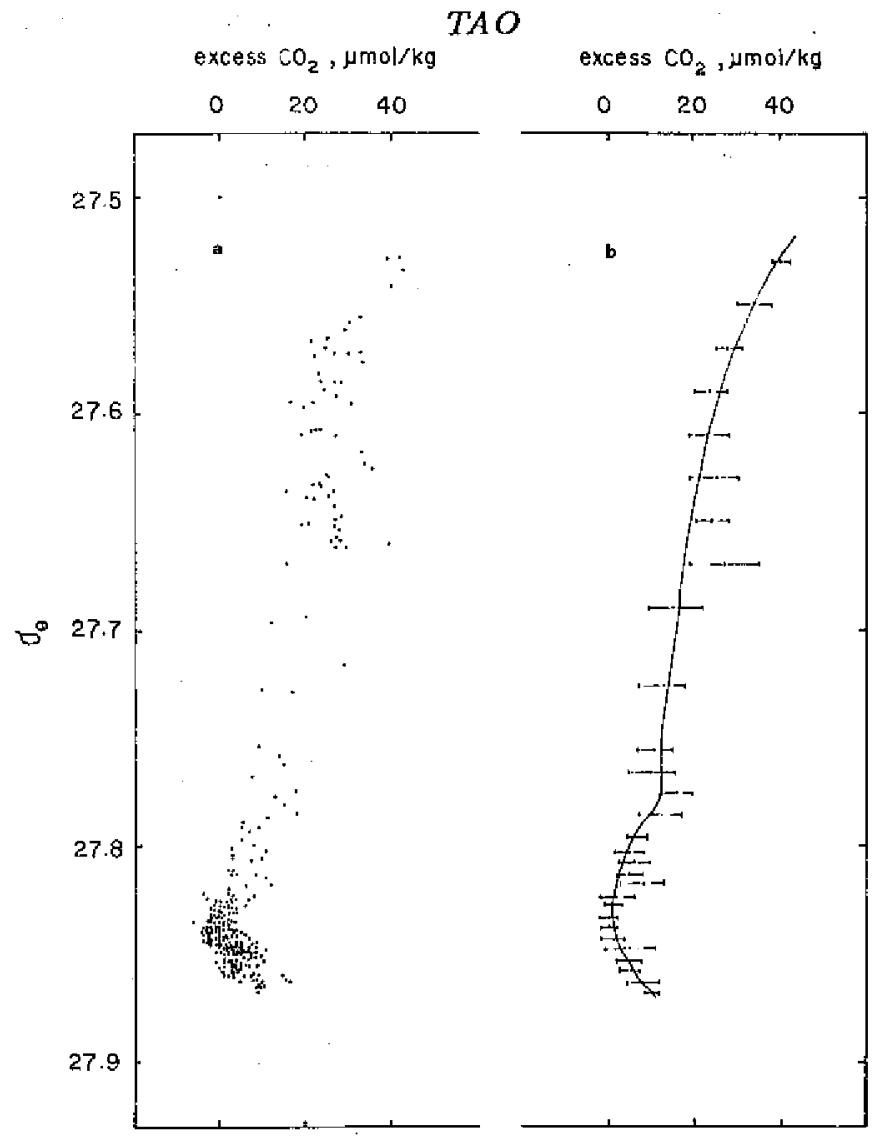

Vol.1, No.1

Fig. 6. (a) Same as Fig. 5a but using SOMOV data. (b) Same as Fig. 5b but using SOMOV data.

salinity for all Antarctic GEOSECS data, separated into Atlantic, Indian and Pacific sectors, are shown in Figs. $8 \mathrm{a}, 8 \mathrm{~b}, 8 \mathrm{c}$. The scatter of the deep-water data for tritium and radiocarbon is obvious (Figs. 8b, $8 \mathrm{c}$ ); these waters, therefore, may appear homogeneous in tritium and radiocarbon content. Salinity as a conservative tracer was chosen for one of the axis so that temporal effects on mixing can be investigated. Overall, the scatter of the radiotracers makes decay determinations difficult, although there is a slight indication of decay in the radiocarbon data. Neither salinity nor temperature is strictly conservative at the very important air-sea interface. Also, mixing and stirring are enhanced near the surface, and surface and pycnocline waters can have large variabilities. Establishing well-defined surface values (except for the freezing curve temperature) is not easy.

The tritium plot (Fig. 8b) indicates that the surface Atlantic and Pacific have significantly higher tritium values than the surface Indian Ocean. The lower value in the Indian Ocean is the result of decay and more reduced atmospheric input in 1978 than in 1972-74. The Atlantic expedition was undertaken in 1972 and the Pacific in 1973-74, while the Indian Expedition took place in 1978 so that in the six-year interim between the Atlantic and Indian expe- 


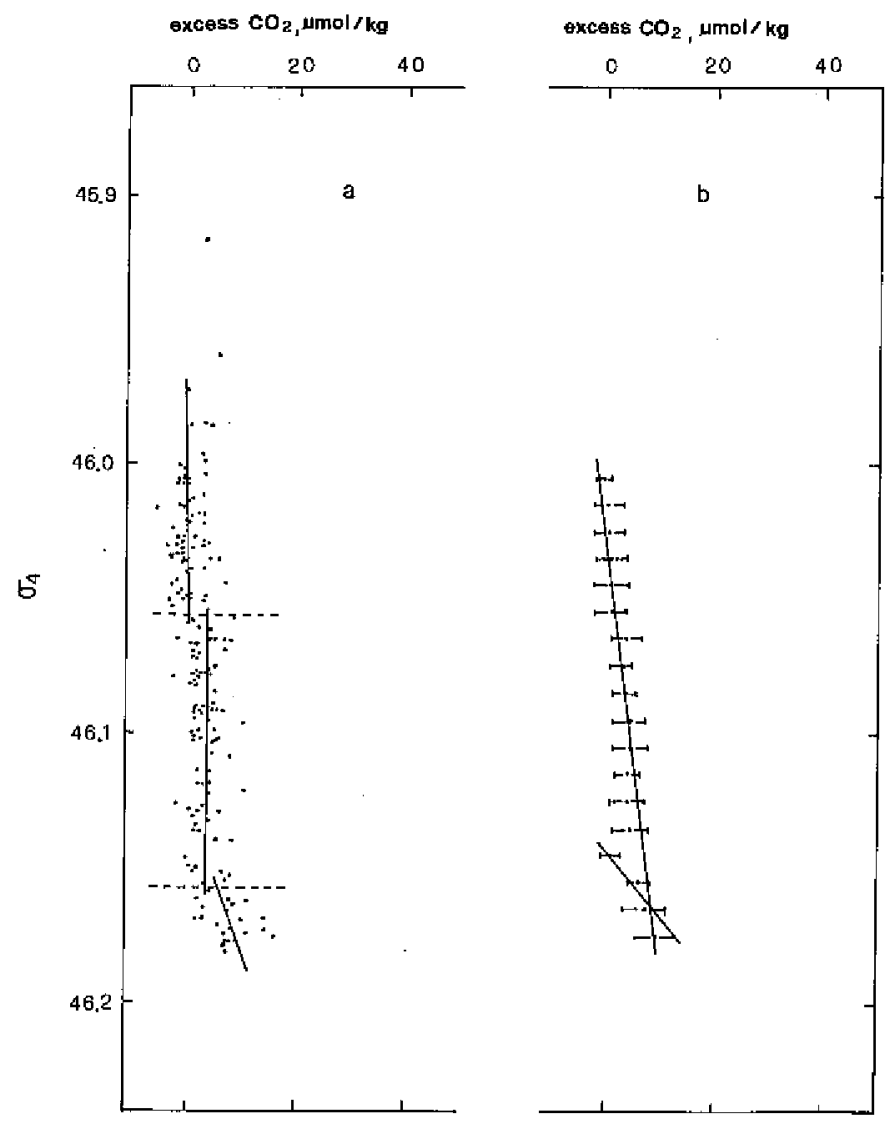

$F i g$. 7. (a) Composite $\sigma_{4}$ vs excess $\mathrm{CO}_{2}$ for SOMOV data below the salinity maximum. Upper dashed line is at 46.056 and lower one is at 46.156 . See text for linear regression lines. (b) Curves fit by eye to average data of $F i g$. $7 \mathrm{a}$.

ditions, tritium could decrease by $30 \%$. The anomalously high tritium and radiocarbon in the salinity range between 34.10 and $34.50 \times 10^{-3}$ is from GS 89 mentioned earlier with respect to Fig. 2.

The one Antarctic Pacific station (GS 287) shows a bottom layer of increasing salinity (Fig. 8a). This increase results from input from the Ross Sea Bottom Water (RSBW) (Jacobs, et al., 1970; Gordon, 1972). When salinity, tritium and radiocarbon are plotted against depth (Figs. 9a, 9b) for station GS 287 , tritium and radiocarbon appear to increase in the deep water column. This salinity maximum near the bottom can be used as a tracer for relatively young bottom water only in the Southeast Indian/Southwest Pacific sector (Gordon, 1972; Rodman and Gordon, 1982).

Silicate, on the other hand, can be used circumpolarly as a tracer for recently formed bottom waters. Excess $\mathrm{CO}_{2}$ data from SOMOV and all Antarctic GEOSECS stations are plotted against silicate in Figs. 10a, 10b. Fig. 10b shows the expanded boxed region of Fig. 10a. Silicate increases from near 

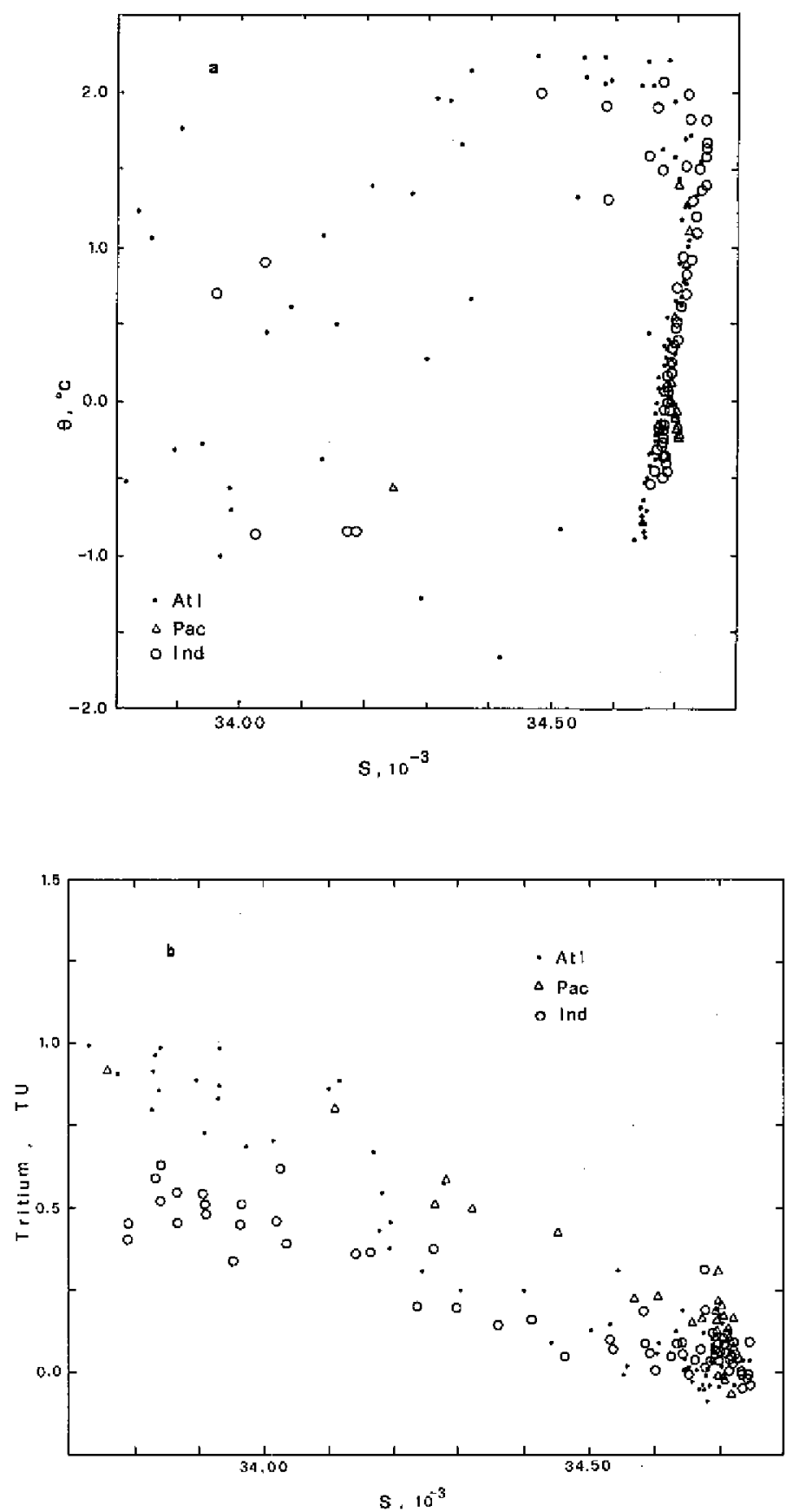

Fig. 8. (a) Potential temperature vs salinity for GEOSECS Antarctic stations: Atlantic (GS 76, 77, 78, 82, 89, 91 - ".); Pacific (GS 287 - " $\triangle$ "); Indian (GS $\left.430,431,432,433-" o^{\prime}\right)$. (b) Tritium vs salinity for stations in $F i g$. 8a. (c) Radiocarbon vs salinity for stations in $F i g$. 8 a.

zero at the surface to a maximum of about $125 \mu \mathrm{mol} / \mathrm{kg}$ then decreases again. 


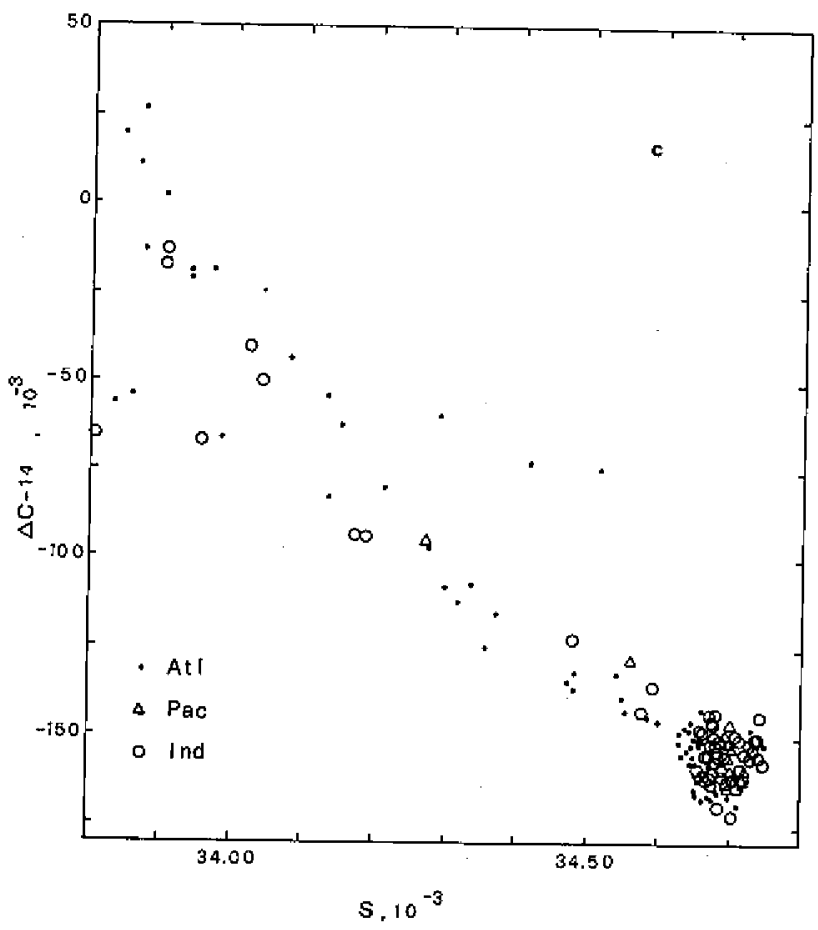

Fig. 8. (Continued)

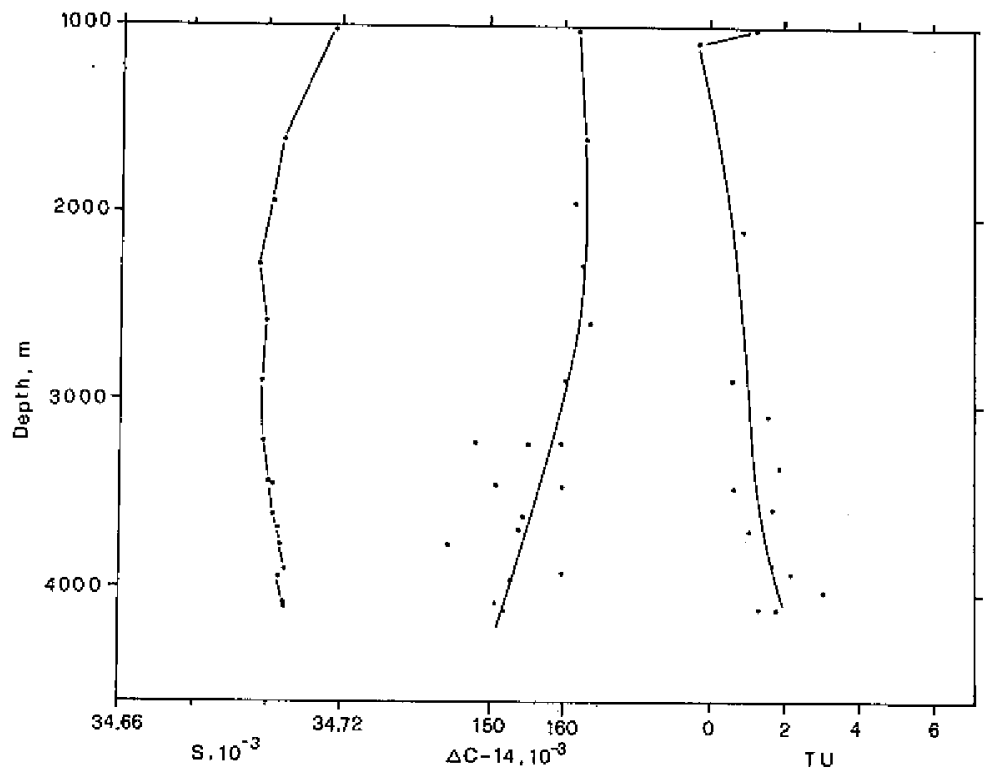

Fig. 9. Salinity, $\Delta C-14$ and tritium below $1000 m$ for GEOSECS Pacific station GS 287.

The lowest silicate (Fig. 10a) is associated with the highest excess $\mathrm{CO}_{2}$, and the general trend shows silicate increasing as excess $\mathrm{CO}_{2}$ decreases; however, near a silicate value of approximately $90 \mu \mathrm{mol} / \mathrm{kg}$ (excess $\mathrm{CO}_{2}$ of 0 ), there is a 
break in the slope. Silicate values of $80-90 \mu \mathrm{mol} / \mathrm{kg}$ lie just above the $S_{\text {max }}$, or within the oxygen minimum layer (see plates $112,113,114$, Gordon et al., 1982). Waters having silicate values greater than $80-90 \mu \mathrm{mol} / \mathrm{kg}$ contain large portions of Circumpolar Deep Water, Weddell Sea Bottem Water and AABW (Rutgers van der Loeff and van Bennekom, 1989), are markedly more aged and contain little or no excess $\mathrm{CO}_{2}$ (Fig. 10a). The deep silicate maximum has been investigated in the Western Weddell Sea by Carmack (1973) and its distribution circumpolarly and globally as an advective feature by Edmond et al. (1979). They were unable, however, to resolve the relative importance of in situ and sea-floor dissolution. Silicate was one of many chemicals Weiss et al. (1979) investigated in their exhaustive study on the geochemistry of the Weddell Sea. Their work indicated that bottom dissolution rather than solution of sinking particulates was probably responsible for the deep silicate enrichment. Nelson and Gordon (1982) in their study south of New Zealand indicate that during the austral spring, in situ dissolution dominates. Rutgers van der Loeff and van Bennekom reported that Weddell Sea contributes little to silicate enrichment in AABW. Although the data in Fig. 10b shows scatter, the resolution is sufficient to show that excess $\mathrm{CO}_{2}$ increases below the silicate maximum. The average increase is $6.3 \pm 1.2 \mu \mathrm{mol} / \mathrm{kg}$. Reduced silicate below the maximum in Antarctic waters is taken to mean relatively younger bottom waters (Carmack, 1973; Weiss et al., 1979), that is, those containing a larger component of surface and/or shelf waters. The somewhat higher excess $\mathrm{CO}_{2}$ values support this assumption. (Poisson and Chen, 1987)

The scatter diagram for tritium vs. excess $\mathrm{CO}_{2}$ is shown in Fig. 11. High tritium is associated with high excess $\mathrm{CO}_{2}$, and tritium also decreases as excess $\mathrm{CO}_{2}$ decreases. The slope of the linear regression line is $0.018 \mathrm{TU} / \mu \mathrm{mol} / \mathrm{kg}$. Since both tritium and excess $\mathrm{CO}_{2}$ are highest in the surface waters and decrease with depth, this distribution is not surprising.

It is possible to estimate the radiocarbon value of surface and near-surface water components in the formation of $A A B W$. The time dependence of radiocarbon is neglected, and conservative mixing is assumed. An average radiocarbon value for all Antarctic GEOSECS stations was calculated in the following manner:

When there existed a bottom silicate gradient, all $\Delta C-14$ values from the top of the gradient down were averaged to give a bottom water value of $(-151.9 \pm 4.9) \times 10^{-3}$, which agrees well with the pre-bomb values reported for Weddell Sea Bottom Water and Antarctic Bottom Water of $-150 \times 10^{-3}$ and $153 \times 10^{-3}$ respectively (Michel and Linick, 1985). Between the $S_{\max }$ and the top of this silicate gradient, or to the bottom if no silicate gradient was present, all values were averaged to give a Circumpolar Deep Water (CDW) value of $(-160.3 \pm 4.2) \times 10^{-3}$. It appears, therefore, that $A A B W$ may be 

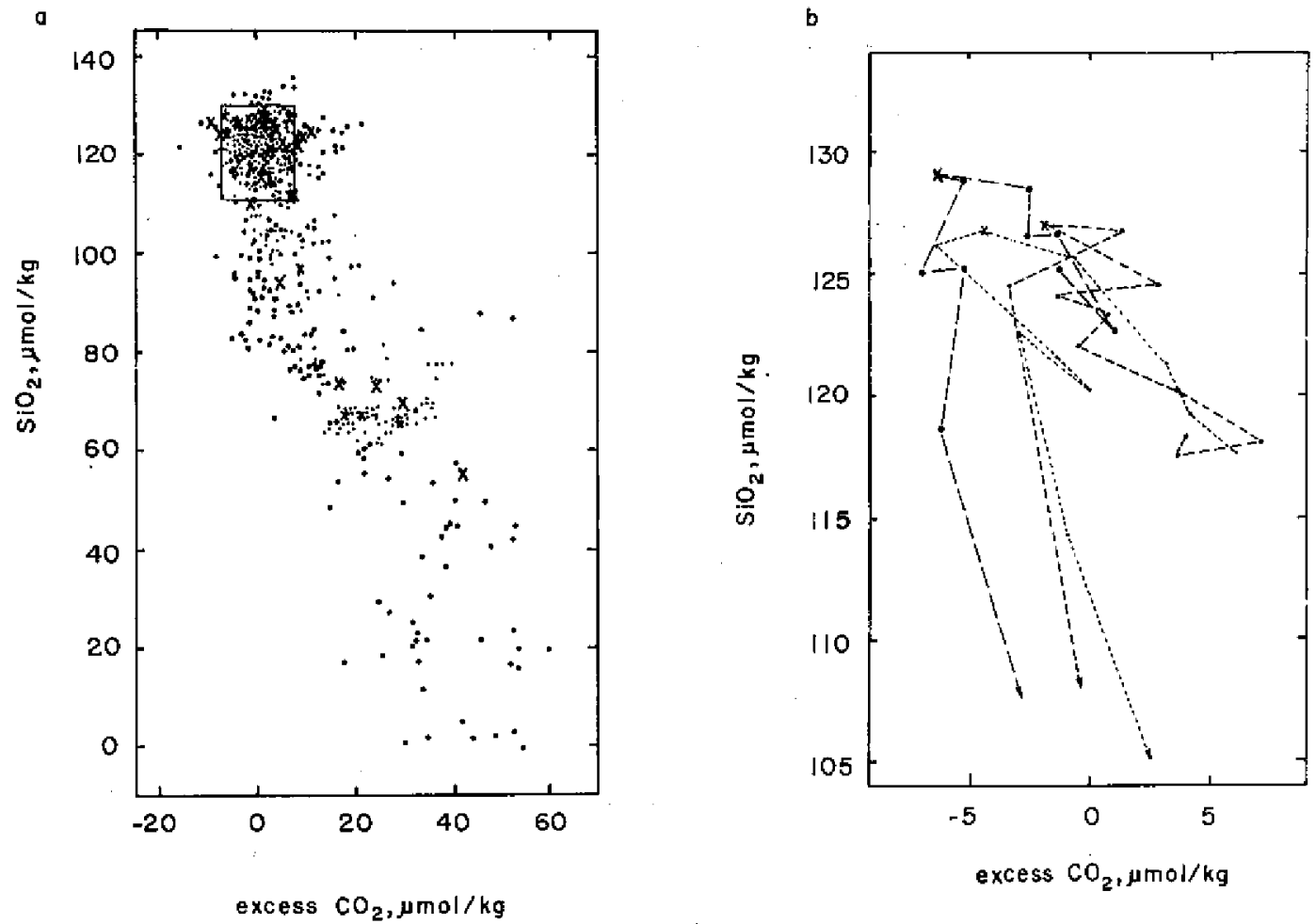

Fig. 10. (a) Silicate vs excess $\mathrm{CO}_{2}$ for the Antarctic GEOSECS and SOMOV stations (The X's are for GS 89). (b) Expanded scale of the "boxed" region in Fig. 10a for near-bottom waters of three SOMOV stations which contain a silicate maximum marked by $\mathrm{X}$ on $\mathrm{b}$ plot only.

slightly younger than CDW, or AABW may contain a little bomb-produced $C-14$. (Note the precision of each $C-14$ determination is $3.5 \times 10^{-3}$ (Stuiver et $a l$, 1983)). This deep water value agrees well with other work (Fiadeiro, 1982; Stuiver et al., 1983; Bolin, 1983; Broecker, 1979). The nature of this silicate gradient vs. potential temperature, with respect to $\theta / S$ and $\theta / \Delta C-14$ is shown in Figs. 12a, 12b, 12c where the two Southern Ocean GEOSECS stations $(82,89)$ having deep radiocarbon values associated with a potential temperature less than $0^{\circ} \mathrm{C}$ are plotted.

Depending on one's choice of end-members, different proportions of deep and shelf-surface water combinations are possible in a complex sequence of mixing processes. Foster and Carmack (1976), however, simplified these processes considerably and arrived at the proportions of $37.5 \%$ near-surface components (12.5\% Winter Water and $25 \%$ Western Shelf Water) and $62.5 \%$ deep-water components. For classical AABW-CDW mixtures the proportion is about $30 \%$ surface components and $70 \% \mathrm{CDW}$, and classical AABW-Weddell Deep Water ratios are $45 \%$ surface and $55 \%$ WDW. As Chen (1984) and Poisson and 


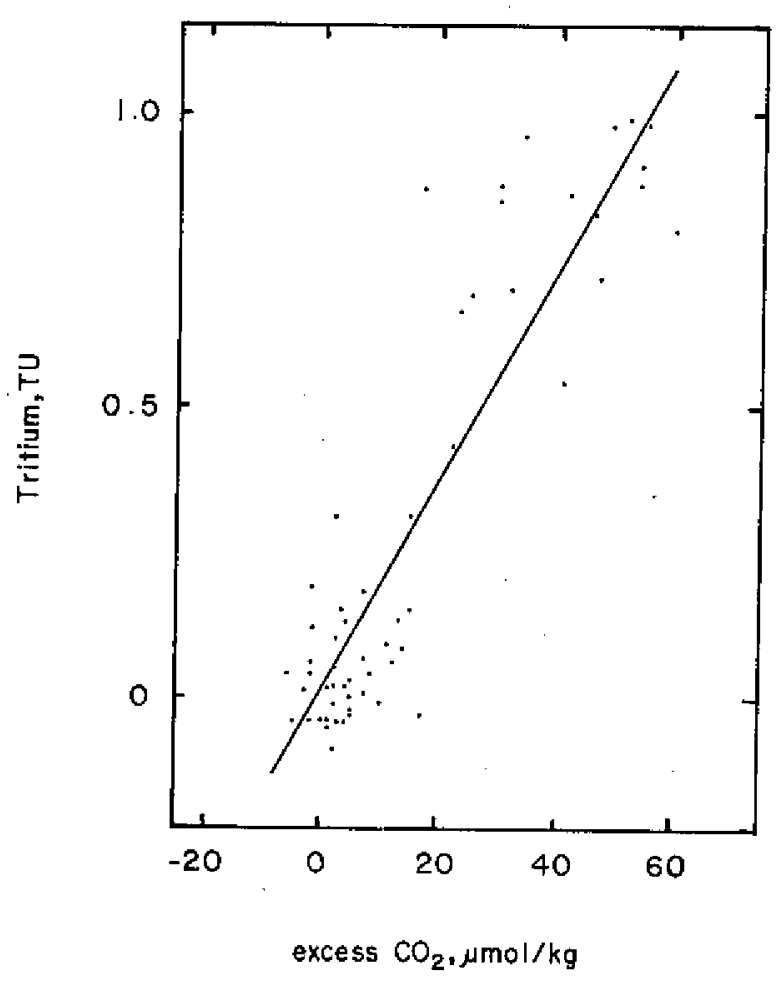

Fig. 11. Tritium vs. excess $\mathrm{CO}_{2}$ for Antarctic GEOSECS data.

Chen (1987) pointed out, the near surface waters in turn have a deep-water component and they reported a 32:68 mixture of WDW to surface water. Gordon et al. (1984) reported a 1:3 ratio and Schlosser et al. (1987) reported a 31:69 ratio of WDW to surface water. Weiss et al. (1979) using a large array of chemical tracers to check the internal consistency of their results estimated that classical AABW was composed of $62 \%$ WDW and $12 \%$ Winter Water and $26 \%$ Western Shelf Water mixtures which supported the earlier work of Foster and Carmack (1976) based on $\theta / S$ analysis. Thus as a first approximation we have used $60 \% \mathrm{WDW}$ and $40 \%$ surface components. This proportion yields an estimate for the surface water radiocarbon content of $-139.3 \times 10^{-3}$. Broecker and Peng (1982), instead, used a $60 \%$ surface water to $40 \%$ deep water ratio and arrived at an estimate of $-146 \times 10^{-3}$. Had we used this $60-40$ surface-to- deep-water mixing ratio, we would have also obtained an estimate of $-146.3 \times 10^{-3}$. But we believe that our estimate of $-139.3 \times 10^{-3}$ for the radiocarbon value is more realistic because the $60 \% \mathrm{WDW}$ and $40 \%$ surface water components estimation is more reliable.

\section{CONCLUSION}




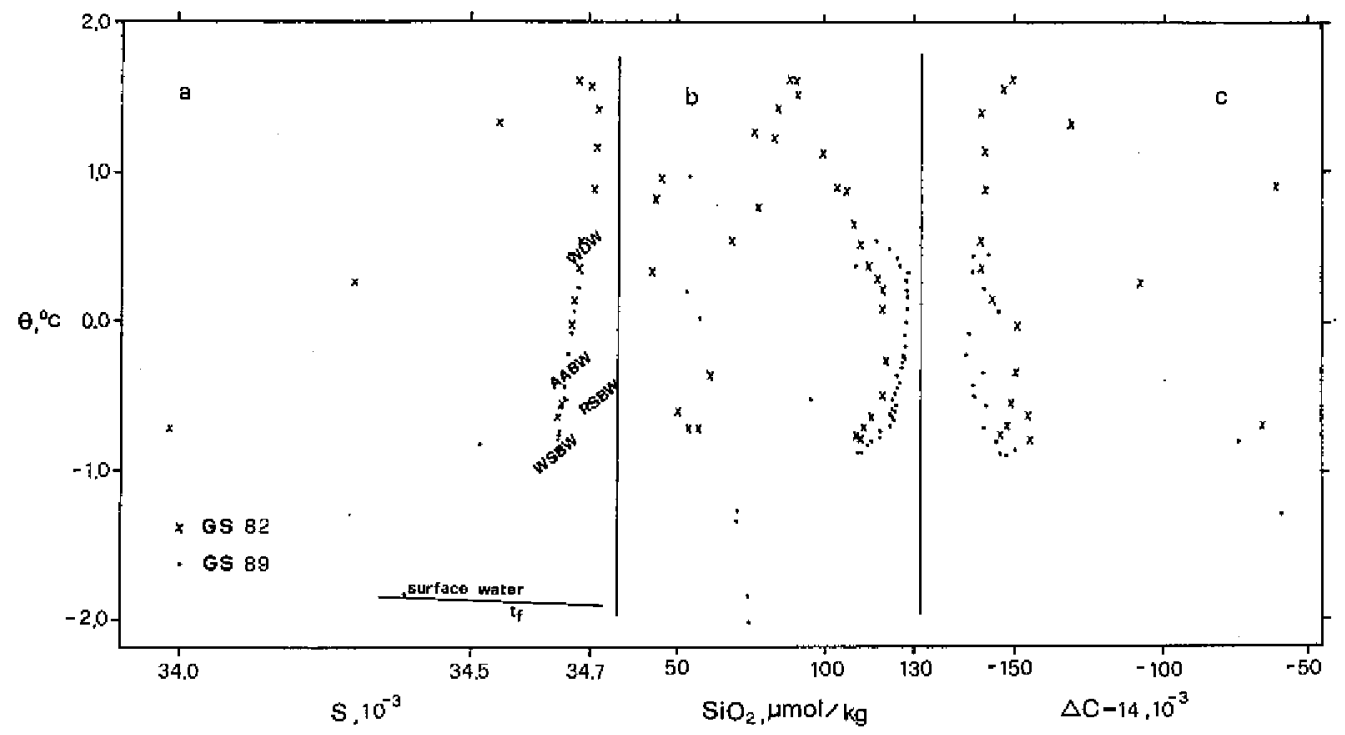

Fig. 12. (a) Potential temperature vs salinity for GEOSECS stations GS 82 ("X") and GS 89 (".") in the Southwest Atlantic. The following water masses have been approximately shown: WSBW (Weddell Sea Bottom Water), AABW (Antarctic Bottom Water), RSBW (Ross Sea Bottom Water), and WDW (Weddell Deep Water). The freezing curve, $t_{f}$, is alsoshown. (b) Same as Fig. 12a but for potential temperature vs silicate. (c) Same as Fig. 12a but for potential temperature vs radiocarbon.

The tritium data have consistently supported the existence of a young component in the bottom waters of the Southern Ocean. The radiocarbon and excess $\mathrm{CO}_{2}$ data as reported in the literature, however, have not provided similar evidence for the existence of a relatively young bottom-water component. Our investigation of the distribution of radiocarbon and excess $\mathrm{CO}_{2}$ with respect to density shows that both parameters have a deep-water-to-bottom-water signal which correlates with the tritium/density distribution. The discrepancy in distribution between tritium and radiocarbon as well as excess $\mathrm{CO}_{2}$, therefore, has been removed. We have also been able to estimate the surface preformed radiocarbon value at $-139.3 \times 10^{-3}$ based on a $60 \%$ WDW and $40 \%$ surface water mixing scheme.

Acknowledgements. This work would not be possible without the excellent GEOSECS and SOMOV data. Preparation of the manuscript was supported by the National Science Council of the Republic of China (NSC 79-0209-M11006). Prof. Y. C. Chung provided valuable comments. 


\section{REFERENCES}

Bainbridge, A. E., 1981: GEOSECS Atlantic Expedition, Vol. 1, Hydrographic Data, NSF.

Bolin, B., 1983: Changing Global Biogeochemistry, in Oceanography: the present and future, ed., P. Brewer, Springer-Verlag, New York, 392pp.

Broccker, W. S., 1979: A revised estimate for the radiocarbon age of North Atlantic Deep Water. J. Geophys. Res., 84, 3218-3226.

Broecker, W. S., 1981: Geochemical tracers and ocean circulation, Evolution of physical oceanography, ed. B. A. Warren and C. Wunsch. The MIT Press, Cambridge, Mass. pp.434-460.

Broecker, W. S. and T. -H. Peng, 1982: Tracers in the sea, Eldigio Press, 690pp. Broecker, W. S., D. W. Spencer and H. Craig, 1982: GEOSECS Pacific Expedition, Vol. 3, Hydrographic Data, NSF.

Carmack, E. C., 1973: Silicate and potential temperature in the deep and bottom waters of the western Weddell Sea. Deep-Sea Res., 20, 927-932.

Carmack, E. C. and P. D. Kilworth, 1978: Formation and interleaving of abyssal water masses off Wilkes Land, Antarctica. Deep-Sea Res., 25, 357-359.

Carmack, E. C. and T. D. Foster, 1975: On the flow of water out of Weddell Sea. Deep-Sea Res., 22, 711-724.

Chen, C. T., 1982: On the distribution of anthropogenic $\mathrm{CO}_{2}$ in the Atlantic and Southern Oceans. Deep-Sea Res., 29, 563-580.

Chen, C. T. A., 1984: Carbonate chemistry of the Weddell Sea. U.S. Department of Energy Technical Report DOE/EV/10611-4, 118pp.

Chen, C. T. A., 1987: On the depth of anthropogenic $\mathrm{CO}_{2}$ penetration in the Atlantic and Pacific Oceans. Oceanologica Acta sp., 97-102.

Chen, C. T. A. and A. Poisson, 1984: Excess carbon dioxide in the Weddell Sea. U.S. Antärtic Journal, 1984 Review, 74-75.

Chen, C. T. A. and M. Rodman, 1984: Inhomogeneous distribution of tracers in the abyssal Southern Ocean. U.S. Antarctic Journal, 1984 Review, 68-69.

Chen, C. T. A. and E. T. Drake, 1986: Carbon dioxide increase in the atmosphere and oceans and possible effects on climate. Annual Review of Earth and Planetary Science, 14, 201-235.

Edmond, J. M., S. S. Jacobs, A. L. Gordon, A. W. Mantyla and R. F. Weiss , 1979: Water column anomalies in dissolved silica over opaline pelagic sediments and the origin of the deep silica maximum. J. Geophys. Res., $84,7809-7826$.

Fiadeiro, M. E., 1982: Three-dimensional modeling of tracers in the deep Pacific Ocean II. Radiocarbon and the circulation. J. Mar. Res., 40, 537-550.

Foster, T. D. and E. C. Carmack, 1976: Frontal zone mixing and Antarctic Bottom Water formation in the Southern Weddell Sea. Deep-Sea Res., 
23, 301-317.

Gordon, A. L., 1972: Spreading of Antarctic bottom water II. In: Studies in Physical Oceanography - atribute to George Wust on his 80th birthday, A.L. Gordon, ed., Gordon and Breach, 2, 1-17.

Gordon, A. L., 1978: Deep Antarctic convection west of Maud Rise. J. Phys. Oceanogr., 8, 600-612.

Gordon, A. L., C. T. A. Chen and W. G. Metcalf, 1984: Winter mixed layer entrainment of Weddell Deep Water. J. Geophys. Res., 89. 637-640.

Gordon, A. L. and B. A. Huber, 1984: Thermohaline stratification below the Southern Ocean sea ice. J. Geophys. Res., 89, 641-648.

Gordon, A. L., E. Molinelli and T. Baker, 1982: Southern Ocean Atlas, Columbia University Press, New York.

Huber, B. A., J. Jennings, C. T. Chen, J. Marra, S. Rennie, P. Mele and A. Gordon, 1983: Reports of the US-USSR Weddell Polynya Expedition: Vol. II - hydrographical data LDGO 83-1, 115pp.

Jacobs, S. S., A. Amos and P. Bruchhausen, 1970: Ross Sea oceanography and Antarctic bottom water formation. Deep-Sea Res., 17, 935-962.

Jacobs, S. S. and D. T. Georgi, 1977: Observations on the Southwest Indian/Antarctic Ocean. In: A Voyage of Discovery, George Deacon 70th Anniversary Volume, M. Angel, ed., Pergamon Press, Oxford, 43-84.

Jenkins, W. J., D. E. Lott, M. W. Pratt and R. D. Boudreau, 1983: Anthropogenic tritium in South Atlantic Bottom Water. Nature, 305, 45-46.

Lynn, R. J. and J. L. Reid, 1968: Characteristics and circulation of deep and abyssal waters. Deep-Sea Res., 15, 577-598.

Martinson, D. G., P. D. Kilworth and A. L. Gordon, 1981: A convective model for the Weddell Polynya. J. Phys. Oceanogr., 11, 466-488.

Michel, R. L., 1978: Tritium distribution in Weddell seawater masses. J. Geophys. Res., 83, 6192-6198.

Michel, R. L. and T. W. Linick, 1985: Uptake of bomb-produced Carbon-14 by the Weddell Sea. Meteoritics, 20, 423-435.

Millero, F. J., C. T. Chen, A. Bradshaw and K. Schleicher, 1980: A new high pressure equation of state of seawater. Deep-Sea Res., 27A, 255-264.

Millero, F. J. and A. Poisson, 1981: International one - atmosphere equation of state of seawater. Deep-Sea Res., 28, 625-629.

Nelson, D. M. and L. I. Gordon, 1982: Production and pelagic dissolution of biogenic silica in the Southern Ocean. Geochimica et Cosmochimica Acta, 46, 491-501.

Ostlund, H. G., H. G. Dorsey and R. Brescher, 1976: Tritium Laboratory Report No. 5, University of Miami, 192pp.

Ostlund, H.G., R. Brescher, R. Oleson and J.M. Ferguson, 1979: Tritium Laboratory Data Report \#8. University of Miami. 
Ostlund, H. G., R. Oleson and R. Brescher, 1980: Tritium Laboratory Data Report \#9. University of Miami.

Poisson, A. and C. T. Chen, 1987: Why is there little anthropogenic $\mathrm{CO}_{2}$ in the Antarctic Bottom Water? Deep-Sea Res., 34, 1255-1275.

Reid, J. L. and R. J. Lynn, 1971: On the influence of the Norwegian- Greenland and Weddell Seas upon the bottom waters of the Indian and Pacific Oceans. Deep-Sea Res., 18, 1063-1088.

Reid, J. L., W. D. Nowlin, Jr. and W. C. Patzert, 1977: On the characteristics and circulation of the southwestern Atlantic Ocean. J. Phys. Oceanogr., $7,62-91$.

Rodman, M. R. and A. L. Gordon, 1982: Southern Ocean bot tom water of the Australian-New Zealand Sector. J. Geophys. Res., 87, 5771-5778.

Rutgers van der Loeff, M. M. and A. J. van Bennekom, 1989: Weddell Sea contributes little to sillicate enrichment in Antarctic Bottom Water. DeepSea Res., 36, 1341-1357.

Schlosser, P. W. Roether and G. Rohardt, 1987: Helium-3 balance of the upper layers of the northwestern Weddell Sea. Deep-Sea Res., 34, 365-377.

Stuiver, M., 1976: The C distribution in west Atlantic abyssal waters. Earth Planet. Sci. Lett., 32, 322-330.

Stuiver, M. and H. G. Ostlund, 1980: GEOSECS Atlantic radiocarbon. Radiocarbon, 22, 1-24.

Stuiver, M., P. Quay and H. G. Ostlund, 1983: Abyssal water Carbon-14 distribution and the age of the world oceans. Science, 219, 849-851.

Weiss, R. F., H. G. Ostlund and H. Craig, 1979: Geochemical studies of the Weddell Sea. Deep-Sea Res., 26, 1093-1120.

Weiss, R. F., W. S. Broecker, H. Craig, D. Spencer, 1983: GEOSECS Indian Ocean Expedition. Vol. 5, Hydrographic Data, NSF.

Wisegarver, D. P., R. H. Gammon and F. A. Menzia, 1989: Vertical distributions of chlorofluoromethanes in the Southeast Pacific Ocean. EOS, 70, 1131. 


\title{
南冰洋深層水中氞及碳14之不均衡分佈
}

\author{
陳釱東 \\ 國立中山大學海洋地質硎究所
}

M. R. Rodman

880 Hoxtel St Gilroy, CA. 95020 , U. S. A.

\section{摘 要}

本文分析GEOSECS 計畫中取得之南冰洋気及碳14 数推。將GEOSECS 於大西洋之 剆站 $76,77,82,85,87,89,91$ 及 SOMOV -81 航次之所有測站所得之過量二氧化碳與碳 14 資料作對比後發現, 這些資料與気一幥, 均顯示於深水中之分佈不平均。本文最後計算出 南極底管水當形成時，其中所含表厤水中碳14之原始值䉆一 $139.3 \times 10^{-3}$ 。 